\title{
Curve Estimation of Rail Based Passenger Transportation in Turkey
}

\section{AKALIN Kadir Berkhan, KARACASU Murat, ERGÜL Barış}

\begin{abstract}
Railways are enjoying a period of significant in Turkey with major investment in high-speed lines to freight and passenger transportation in major cities across the country. The main aim of this paper is to modeling the level of rail based passenger transportation in Turkey. Curve estimation passenger demand model is using annual data of passenger transportation from 1977 to 2013. Some estimated models was used to model the rail based passenger transportation data from 1977 to 2013. Cubic estimation model showed that number of rail based passenger in Turkey would continue to increase.
\end{abstract}

Keywords - transportation, curve estimation, Turkey, railway, railroad, passenger

\section{Introduction}

Rail systems currently used in both passenger and freight services have priority in most of the country's transport planning. The reason for the system of having the highest priority is best served system for the fundamental objective of today's sustainable transport policy. Moreover factors in large cities such as population growth, expansion of urban areas, distribution of population density to different regions, transportation costs, environmental impacts, safe, fast and comfortable travel choice require the rail systems instead of highway monopoly from low capacity transport to high capacity transport like preferred bus line. Thus we see very efficiently designed rail system infrastructure in today's main town. The advantages of the railway transport are to provide mass transportation in both long and short distances, low energy consumption per unit transport compared to the other systems because of the low friction between metal wheel and metal railroad, the lack of traffic problems, safe, comfortable and fast travel opportunities in recent years [1].

The aim of this study is to estimate the number of passengers travelling by railway in the future by using the number of railway passengers we know.

AKALIN Kadir Berkhan, KARACASU Murat

Eskișehir Osmangazi University, Faculty of Engineering and Architecture TURKEY

ERGÜL Barıs

Eskişehir Osmangazi University, Faculty of Science and Letter TURKEY
In this study, the number of passengers using rail travel in Turkey in the period between 1977 and 2013 is taken annually data from Turkey Statistical Institute.

In the second part of the study, the Curve Estimation technique is described. The number of railway passengers is predicted by using Curve Estimation technique for the period between 1977 and 2013 in the third chapter. Then the results which obtained by Curve Estimation are given. The fourth section which is the conclusion part has general comments

\section{Material and Method}

In many cases, the relationship between two variables may be geometric or exponential. Assume that the mean of the dependent variable $Y$ grows geometrically or exponentially as $X$ increases.

Curve fitting, statistical technique used to derive coefficient values for equations that express the value of $Y$ as a function of $X$.

A geometric or exponential model can be appropriate if it is thought that the slope of the effect of $X_{\mathrm{i}}$ on $\mathrm{E}(Y)$ changes sign as $X_{\mathrm{i}}$ increases. For many such models, the relationship between $X_{\mathrm{i}}$ and $\mathrm{E}(Y)$ can be accurately reflected with a specification in which $Y$ is viewed as a function of $X_{\mathrm{i}}$ and one or more powers of $X_{\mathrm{i}}$

In these methods, the linear equation that will minimize the sum of squared errors is investigated and the model which has maximum $\mathrm{R}^{2}$ value which is coherence measure is the best model [2].

\section{Rail Based Passenger Transportation}

Graphics are drown for geometrical and exponential models by using data. The graphics for the data sets are shown in Figure 1. The parameters of these curves and $\mathrm{R}^{2}$ values are shown in Table $1-4$. 


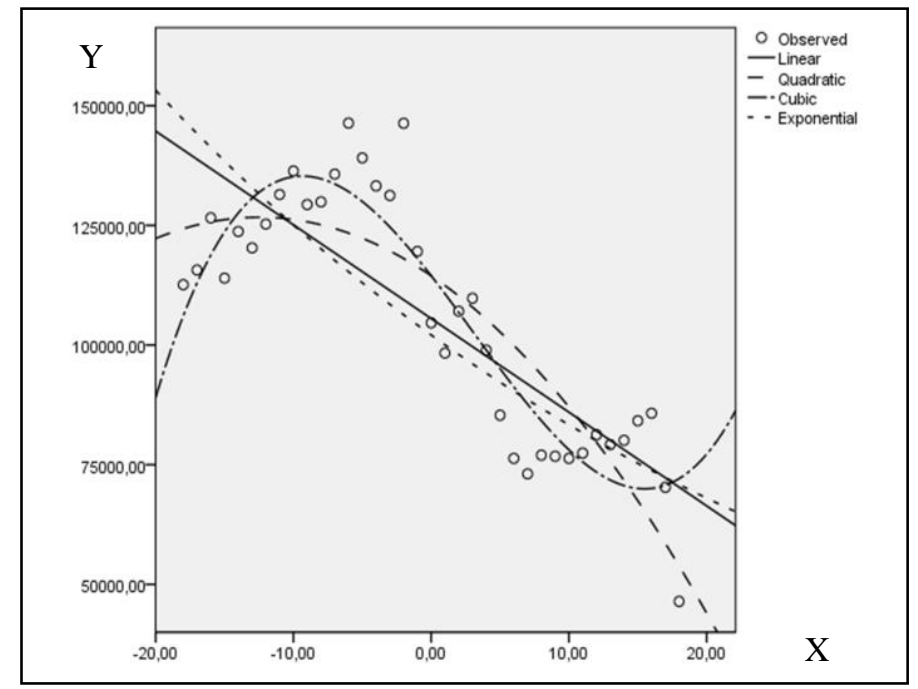

Figure 1. Curve Of Rail Based Passenger Transportation

$\mathrm{X}$ is taken as time variable and $\mathrm{Y}$ is taken as the number of passengers traveling on the railways.

TABLE 1. MODEL PARAMETERS FOR LINEAR

\begin{tabular}{|c|c|c|c|c|c|}
\hline Parameters & Estimate & SE & t & Sig. & $\mathbf{R}^{2}$ \\
\hline Constant & 105534.00 & 2554.57 & 41.32 & 0.000 & 0.647 \\
\hline $\mathrm{x}$ & -1957.22 & 239.26 & -8.18 & & \\
\hline
\end{tabular}

TABLE 2. MODEL PARAMETERS FOR QUADRATIC

\begin{tabular}{|c|c|c|c|c|c|}
\hline Parameters & Estimate & SE & $\mathbf{t}$ & Sig. & $\mathbf{R}^{2}$ \\
\hline Constant & 114471.90 & 3302.77 & 34.66 & 0.000 & 0.738 \\
\hline $\mathrm{x}$ & -1957.22 & 206.09 & -9.50 & 0.001 & \\
\hline $\mathrm{x}^{2}$ & -78.40 & 21.61 & -3.63 & 0.000 & \\
\hline
\end{tabular}

TABLE 3. MODEL PARAMETERS FOR CUBIC

\begin{tabular}{|c|c|c|c|c|c|}
\hline Parameters & Estimate & SE & $\mathbf{t}$ & Sig. & $\mathbf{R}^{2}$ \\
\hline Constant & 114471.90 & 2596.64 & 44.09 & 0.000 & 0.838 \\
\hline $\mathrm{x}$ & -3704.17 & 406.12 & -9.12 & 0.000 & \\
\hline $\mathrm{x}^{2}$ & -78.40 & 16.99 & -4.62 & 0.000 & \\
\hline $\mathrm{x}^{3}$ & 8.52 & 1.82 & 4.69 & 0.000 & \\
\hline
\end{tabular}

TABLE 4. MODEL PARAMETERS FOR EXPONENTIAL ${ }^{*}$

\begin{tabular}{|c|c|c|c|c|c|}
\hline Parameters & Estimate & SE & t & Sig. & $\mathbf{R}^{2}$ \\
\hline Constant & 102091.82 & 2647.93 & 38.56 & 0.000 & 0.657 \\
\hline $\mathrm{X}$ & -0.02 & 0.002 & -8.36 & 0.000 & \\
\hline \multicolumn{5}{|c|}{$*: Y$ variable is obtained as $\ln (\mathrm{Y})$} \\
\hline
\end{tabular}

When tables are examined it can be seen that the cubic model gives the maximum value for $\mathrm{R}^{2}$. Moreover it is understood that the parameter estimates of the model is significant. Therefore, the cubic model parameters will be used while making future predictions.

\section{Conclusion}

In this study, the number of passengers using rail travel in Turkey in the period between 1977 and 2013 is taken annually data from Turkey Statistical Institute. These data sets were analyzed by Curve Estimation technique.

Predictions for railway passengers in Turkey for the period between 2014 and 2016 are made by the cubic model which is defined by analysis result shown in Table 5 .

TABLE 5. FORECAST FOR RAIL BASED PASSENGER TRANSPORTATION

\begin{tabular}{|c|c|}
\hline Period & Estimate Value of Number of Railway Passengers \\
\hline 2014 & 74241 \\
\hline 2015 & 77203 \\
\hline 2016 & 81030 \\
\hline
\end{tabular}

Cubic estimation model showed that number of railway based passenger in Turkey would continue to increase.

\section{References}

[1] C. Kurt, "Türkiye'de Ulaşım Sektörü İçerisinde Lojistiğin Yeri ve Önemi," 2010.

[2] W. H. Greene, Econometric Analysis, 5th ed., Prentice Hall. New Jersey, 2003.
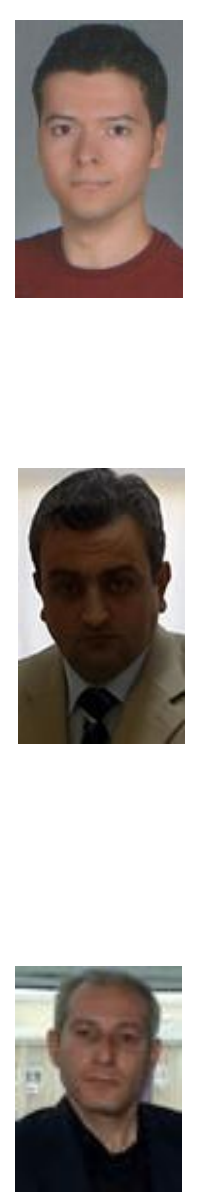

\section{AKALIN, Kadir Berkhan}

He was born on 02.06.1990 in İzmir TURKEY. He graduated from Eskişehir Osmangazi University Engineering and Architecture Faculty Civil Engineering Department and ranked first among all students graduating from the university with $3.95 / 4.00$ GPA in 2013.

$\mathrm{He}$ continues studying both in MSc.

Transportation Engineering at Istanbul Technical University and MSc. Railway Engineering at Eskişehir Osmangazi University.

\section{KARACASU, Murat}

Assoc. Prof. Dr. in civil engineering department transportation division at Eskişehir Osmangazi University, TURKEY

He was born in 1973 in Afyon, TURKEY.

$\mathrm{He}$ graduated from Eskişehir Osmangazi University Engineering and Architecture Faculty Civil Engineering Department and ranked first in department in 1994 and graduated from MSc. Transportation Engineering in 1996.

$\mathrm{He}$ finished his $\mathrm{PhD}$. Degree education in Istanbul Technical University in 2007.

\section{ERGÜL, Barıș}

He graduated from Eskişehir Osmangazi University Science and Letters Faculty Statistics Department in 1998.

He continues his $\mathrm{PhD}$. education in Applied Statistics at Eskişehir Osmangazi University. 